\title{
Metabolic Studies and Clinical Observations during L-Dopa Treatment of Parkinson's Disease
}

\author{
M. J. T. PEASTON, ${ }^{*}$ M.B., PH.D., M.R.C.P. (LOND. AND GLASG.) ; J. R. BIANCHINE, † M.D.
}

\begin{abstract}
Cummary: Twenty-two patients with. Parkinson's disease were treated for the periods. of up to six months with L-dopa. In nine of the male patients metabolic observations were made after oral administration of ${ }^{14} \mathrm{C}$ - $\mathrm{L}$-dopa.

Peak serum levels of total radioactivity represented small fractions of the dose given and occurred at one to two hours after ingestion. Two-thirds of the dose was excreted as metabolites in urine in eight hours. Insignificant fractions of the dose were excreted in stool and expired air. These results indicate rapid and complete absorption from the gastrointestinal tract, as well as rapid distribution and excretion. Clinical observations confirmed that L-dopa is an effective treatment for Parkinson's disease. Improvements in disability averaged $47 \%$ at 30 days, $55 \%$ at 50 days, and $60 \%$ at three months. Degree of improvement tended to be inversely related to age of patient, duration of illness, and severity of disease. Side-effects were seen in most patients, but were always reversible with dose reduction. Nausea was the chief dose-limiting side-effects in early therapy and choreoathetosis after two months of treatment. The average tolerated daily dose was $3 \mathrm{~g}$. On the basis of this experience it seems that the drug can be used safely and effectively on an outpatient basis provided that dosage increments are introduced gradually, maximum dosage is limited to $4 \mathrm{~g}$. a day, and supervision is both close and continuous.
\end{abstract}

\section{Introduction}

L-Dopa (L-3, 4-dihydroxyphenylalanine) has been shown in several studies to be of definite benefit to patients with Parkinson's disease (Cotzias et al., 1968, 1969; Yahr et al., 1968; Calne et al., .1969; Godwin-Austen et al., 1969). Comparatively little, however, is known of the metabolism of this amino-acid after oral administration of the large doses now regularly used for therapeutic purposes. The present study was undertaken to provide information on the absorption and excretion of ${ }^{14} \mathrm{C}$-labelled drug in Parkinsonian patients and to augment the clinical information on the efficacy of the drug by a structured study, objective measurements being used to assess progress.

\section{Patients}

A group of 22 patients was selected in whom to study Ldopa metabolism and assess clinical response to medication. They were chosen on the basis of an established diagnosis of

* Merck Foundation International Fellow in Clinical Pharmacology. Present Address: Department of Pharmacology and Therapeutics, Liverpool University, Liverpool 3.

† Division of Clinical Pharmacology, Department of Medicine, Johns Hopkins University School of Medicine, Baltimore, Maryland, U.S.A.
Parkinson's disease with classical features of rigidity, tremor, and bradykinesia, with symptoms and signs that had shown progression since the diagnosis was made. Their ages ranged from 53 to 78 years (Table I). Subjects were excluded if there was a past history of hypertension, emotional disturbance, prostatism or incontinence. Three had undergone stereotactic surgery from one to four years before receiving L-dopa. Sixteen were already receiving other drugs for the treatment of Parkinson's disease.

All subjects were evaluated as outpatients, and the degree of disability was assessed by scoring scales for rigidity, tremor, gait, posture, functional capacity, and speech. The scoring scales used were modified after those described by Alba et al. (1968). Additionally, assessmentr included handwriting and ability to draw accurately 10 concentric circles. Bilateral manual motor performance was measured on a randomized multiple-lamp apparatus linked to a differential and integrated analogue computer (Johns and Draper, 1964). The evaluations were repeated at four-week intervals during Ldopa medication,..and each patient's progress was assessed as percentage improvement in his original disability. The first 10 patients were in hospital for a period of 10 days, and L-dopa was started on the third day after admission in a dose of 500 mg. daily. Dosage was gradually increased by $500 \mathrm{mg}$. daily until a total of $4 \mathrm{~g}$. a day in four divided doses was being given, or until the emergence of side-effects (chiefly nausea) limited further increase. If nausea supervened the dose was reduced by $1 \mathrm{~g}$. a day and medication continued at the lower level. Previous medication with other anti-Parkinson drugs was continued unchanged. Later patients were started on the drug on an outpatient basis, with dose increases at more infrequent intervals.

\section{Metabolic Studies}

The metabolic studies were conducted on nine of the male patients, divided into three groups. The three subjects in group A received orally $4 \mathrm{mg}$. of ${ }^{14} \mathrm{C}-\mathrm{L}$-dopa with a specific activity of $26 \mu \mathrm{Ci}$ per mg. (Amersham-Searle). Serum and urine total radioactivity were followed for eight hours and stool for 48 hours. The remaining six patients (group B) were given per os $100 \mu \mathrm{Ci}$ of ${ }^{14} \mathrm{C}-\mathrm{L}$-dopa (Hoffman-La Roche, Ro. 54759) in an identical gelatin capsule. Serum, urine, expired air, and stool were analysed for radioactivity. Blood samples were drawn at one, two, three, four, six, and eight hours, and expired air and urine samples collected at the same times. Urine collections were continued until 12, 24, and 48 hours, and stool collections were made for $\mathbf{4 8}$ hours after ingestion of the drug. After three of these six subjects had received L-dopa in therapeutic doses for 100 days (group C), metabolic studies were repeated over an eight-hour period for blood and urine radioactivity following a further dose of $100 \mu \mathrm{Ci}$ of ${ }^{14} \mathrm{C}-\mathrm{L}$ dopa, given together with a similar dose of the non-radioactive pure L-dopa. 
TABLE I.-The Patients

\begin{tabular}{|c|c|c|c|c|c|c|c|c|c|}
\hline \multirow{3}{*}{$\begin{array}{c}\text { Case } \\
\text { No. }\end{array}$} & \multirow{2}{*}{\multicolumn{2}{|c|}{$\begin{array}{c}\text { Sex and } \\
\text { Age }\end{array}$}} & \multirow{3}{*}{$\begin{array}{c}\begin{array}{c}\text { Duration } \\
\text { of Illness } \\
\text { (years) }\end{array} \\
4 \\
4 \\
13 \\
\end{array}$} & \multirow{3}{*}{\begin{tabular}{l}
\multicolumn{1}{c}{$\begin{array}{c}\text { Concurrent } \\
\text { Therapy }\end{array}$} \\
Diphenhydramine \\
Benzhexol \\
Diphenhydramine, \\
Procyclidine
\end{tabular}} & \multirow{3}{*}{$\begin{array}{c}\begin{array}{c}\text { Maximum } \\
\text { Dose of } \mathrm{L}-\mathrm{Dopa} a \\
\text { (g./day) }\end{array} \\
\mathbf{4} \\
\mathbf{4} \\
\mathbf{4}\end{array}$} & \multirow{3}{*}{$\begin{array}{c}\begin{array}{c}\text { Maintenance } \\
\text { Dose of } \mathrm{L}-\text { Dopa } \\
\text { (g./day) }\end{array} \\
4 \\
3 \frac{1}{2} \\
3\end{array}$} & \multicolumn{2}{|c|}{$\%$ Improvement at } & \multirow{3}{*}{\begin{tabular}{l}
\multicolumn{1}{c}{$\begin{array}{c}\text { Reason for Reducing } \\
\text { L-Dopa }\end{array}$} \\
$\begin{array}{l}\text { Nausea } \\
\text { Depression }\end{array}$
\end{tabular}} \\
\hline & & & & & & & \multirow{2}{*}{$\begin{array}{c}30 \text { days } \\
35 \\
52 \\
42\end{array}$} & \multirow{2}{*}{$\begin{array}{c}50 \text { days } \\
43 \\
48 \\
44\end{array}$} & \\
\hline & $\begin{array}{l}M \\
M \\
M\end{array}$ & $\begin{array}{l}68 \\
59 \\
63\end{array}$ & & & & & & & \\
\hline 4 & $M$ & 57 & 4 & $\begin{array}{l}\text { Benzhexol, } \\
\text { Diphenhydramine }\end{array}$ & 4 & 2 & 64 & 73 & Choreoathetosis \\
\hline 5 & M & 57 & 5 & $\begin{array}{l}\text { Benzhexol, } \\
\text { Orphenadrine }\end{array}$ & $4 \frac{1}{2}$ & $4 \frac{1}{2}$ & 41 & 42 & \\
\hline $\begin{array}{r}6 \\
7 \\
8 \\
9 \\
10\end{array}$ & $\begin{array}{l}M \\
M \\
F \\
F \\
M\end{array}$ & $\begin{array}{l}78 \\
78 \\
72 \\
65 \\
69\end{array}$ & $\begin{array}{r}10 \\
2 \\
3 \\
6 \\
2\end{array}$ & $\begin{array}{l}\text { Procyclidine } \\
\text { Benzhexol } \\
\text { Benztropine } \\
\text { Benzhexol, } \\
\text { Orphenadrine }\end{array}$ & $\begin{array}{l}4 \\
3 \\
4 \\
4 \\
4\end{array}$ & $\begin{array}{l}3 \\
2 \\
2 \\
3 \\
3\end{array}$ & $\begin{array}{r}32 \\
44 \\
47 \\
52 \\
100\end{array}$ & $\begin{array}{l}42 \\
57 \\
62 \\
57 \\
94\end{array}$ & $\begin{array}{l}\text { Nausea } \\
\text { Nausea } \\
\text { Hallucinations, nausea } \\
\text { Nausea } \\
\text { Choreoathetosis, nausea }\end{array}$ \\
\hline $\begin{array}{l}11 \\
12 \\
13 \\
14 \\
15 \\
16 \\
17 \\
18 \\
19 \\
20 \\
21 \\
22\end{array}$ & $\begin{array}{l}M \\
M \\
M \\
M \\
M \\
M \\
F \\
M \\
F \\
F \\
M \\
M\end{array}$ & $\begin{array}{l}72 \\
69 \\
63 \\
56 \\
59 \\
65 \\
76 \\
53 \\
55 \\
77 \\
66 \\
67\end{array}$ & $\begin{array}{r}9 \\
4 \\
6 \\
2 \\
3 \\
8 \\
15 \\
2 \\
5 \\
13 \\
2 \\
4\end{array}$ & $\begin{array}{l}\text { Benzhexol } \\
\text { Ex-10-029 } \\
\text { Ex-10-029 } \\
\text { Benzhexol } \\
\text { Benzhexol }\end{array}$ & $\begin{array}{c}4 \\
4 \\
3 \frac{1}{2} \\
3 \\
3 \frac{1}{2} \\
3 \frac{1}{2} \\
1 \frac{1}{2} \\
3 \\
3 \frac{1}{2} \\
6 \\
4 \\
4\end{array}$ & $\begin{array}{c}3 \\
3 \frac{1}{2} \\
3 \\
3 \\
2 \frac{1}{2} \\
3 \frac{1}{2} \\
1 \frac{1}{4} \\
3 \\
3 \\
3 \\
3 \\
3 \frac{1}{2}\end{array}$ & $\begin{array}{l}15 \\
32 \\
38 \\
63 \\
35 \\
63 \\
35 \\
93 \\
41 \\
29 \\
29 \\
36\end{array}$ & $\begin{array}{l}25 \\
46 \\
62 \\
86 \\
51 \\
74 \\
40 \\
80 \\
53 \\
40 \\
32 \\
68\end{array}$ & $\begin{array}{l}\text { Nausea } \\
\text { Tremor } \\
\text { Nausea } \\
\text { Nausea, choreoathetosis } \\
\text { Nausea, headache } \\
\text { Nausea, confusion } \\
\text { Nausea, vomiting } \\
\text { Nervousness, agitation } \\
\text { Nausea }\end{array}$ \\
\hline
\end{tabular}

\section{Methods}

Serum.-After $0.2 \mathrm{ml}$. of fresh serum was digested in a scintillation phial with $3 \mathrm{ml}$. of hydroxide of Hyamine for 30 minutes at $60^{\circ} \mathrm{C}$., $10 \mathrm{ml}$. of Toluene Liquifluor (New England Nuclear Corporation) was added and total radioactivity measured in a Packard Tricarb Liquid Scintillation Spectrometer (model 3375). All counts were corrected for quench to disintegration per minute with the Packard Automatic External Standard.

Urine.-Urine collections were made in polyethylene bottles containing $10 \mathrm{ml}$. of $1 \mathrm{~N} \mathrm{HCl}$. The volume was measured, and $0.2 \mathrm{ml}$. of the sample was mixed in a scintillation phial with 1 ml. of hydroxide of Hyamine. The sample was then counted in $10 \mathrm{ml}$. of Bray's (1960) solution.

Expired Air.-Expired air was sampled by obtaining 15litre volumes of expired air in a meteorological balloon attached to a rubber mouthpiece. Exhaled water vapour was removed in a trap surrounded by dry ice and acetone. The whole of each sample was then bubbled by vacuum extraction through two tubes in series, containing respectively $20 \mathrm{ml}$. and $10 \mathrm{ml}$. of hydroxide of Hyamine. Then $1 \mathrm{ml}$. of each sample was counted for adsorbed ${ }^{14} \mathrm{CO}_{2}$ in $10 \mathrm{ml}$. of Bray's solution (Fredrickson and Ono, 1958).

Stool.-Combined 48-hour stool collections were weighed and homogenized in a Waring Blendor. Two mixed aliquots of each sample were dried to constant weight and flashcombusted with infrared light under oxygen in glass flasks sealed with a rubber septum. After combustion, $3 \mathrm{ml}$. of hydroxide of Hyamine was injected through the septum, and the ${ }^{14} \mathrm{CO}_{2}$ adsorbed in solution was then counted (Kelly et al., $1961)$.

\section{Metabolic Study}

\section{Results}

Mean serum levels of total radioactivity expressed as percentage of the dose administered are shown in Table II. Peak

TABle II.-Mean Serum Total Radioactivity (Percentage Dose $\times 10^{4}$ )

\begin{tabular}{|c|c|c|c|c|c|c|c|c|c|c|}
\hline \multirow{2}{*}{ Group } & \multirow{2}{*}{$\begin{array}{l}\text { No. } \\
\text { of } \\
\text { Cases }\end{array}$} & \multirow{2}{*}{$\begin{array}{c}\text { Dose of } \\
\text { L-Dopa } \\
\text { (mg.) }\end{array}$} & \multirow{2}{*}{$\begin{array}{c}\text { Dose of } \\
{ }^{14} \mathrm{C} \\
\mathrm{L}-\mathrm{D} \text { opa } \\
(\mu \mathrm{Ci})\end{array}$} & \multirow{2}{*}{$\begin{array}{c}\text { Pre- } \\
\text { treatment } \\
\text { with } \\
\text { L-Dopa }\end{array}$} & \multicolumn{6}{|c|}{ Hours } \\
\hline & & & & & 1 & 2 & 3 & 4 & 6 & 8 \\
\hline $\begin{array}{l}\mathbf{A} \\
\mathbf{B} \\
\mathbf{C}\end{array}$ & $\begin{array}{l}3 \\
6 \\
3\end{array}$ & $\begin{array}{r}4 \\
500 \\
540\end{array}$ & $\begin{array}{l}100 \\
100 \\
100\end{array}$ & $\begin{array}{l}- \\
\begin{array}{l}\text { 3g./day } \\
\text { for } \\
100 \text { days }\end{array}\end{array}$ & $\begin{array}{r}28 \cdot 4 \\
18 \cdot 3 \\
9 \cdot 7\end{array}$ & $\begin{array}{l}27 \cdot 6 \\
19 \cdot 5 \\
14 \cdot 4\end{array}$ & $\begin{array}{l}17 \cdot 8 \\
13 \cdot 7 \\
12 \cdot 3\end{array}$ & $\begin{array}{r}12 \cdot 6 \\
9.9 \\
9 \cdot 2\end{array}$ & $\begin{array}{l}6 \cdot 7 \\
5 \cdot 1 \\
4 \cdot 7\end{array}$ & $\begin{array}{l}3 \cdot 1 \\
3 \cdot 3 \\
3 \cdot 1\end{array}$ \\
\hline
\end{tabular}

serum levels occurred at one hour in group $\mathbf{A}$ and at two hours in groups $\mathrm{B}$ and $\mathrm{C}$. The larger the dose of L-dopa given, the smaller the peak percentage radioactivity in serum. In groups $\mathrm{B}$ and $\mathrm{C}$, with doses in the therapeutic range, patients pretreated with L-dopa for 100 days showed smaller peak serum percentage levels than those not pretreated. Three hours after drug ingestion curves of radioactivity were similar in the three groups.

Mean cumulative excretion of radioactivity in the three groups is shown in Table III. The major route of excretion

\begin{tabular}{|c|c|c|c|c|c|c|}
\hline \multirow{2}{*}{ Group } & \multirow{2}{*}{$\begin{array}{c}\text { Hours } \\
1 \\
2 \\
4 \\
6 \\
8 \\
48\end{array}$} & \multicolumn{2}{|c|}{$\begin{array}{c}\text { Urine } \\
\text { Mean } \\
( \pm \text { S.E. of Mean })\end{array}$} & \multicolumn{2}{|c|}{$\begin{array}{c}{ }^{14} \mathrm{CO}_{2} \\
\text { Mean } \\
\left( \pm \text { S.E. of Mean } \times 10^{3}\right)\end{array}$} & \multirow{2}{*}{$\begin{array}{l}\begin{array}{r}\text { Stool } \\
\text { Mean }\end{array} \\
0.05\end{array}$} \\
\hline & & $\begin{array}{r}6 \cdot 3 \\
24 \cdot 8 \\
48 \cdot 9 \\
58 \cdot 8 \\
67 \cdot 8\end{array}$ & $\begin{array}{l}(2 \cdot 67) \\
(3 \cdot 39) \\
(2 \cdot 19) \\
(2 \cdot 42) \\
(1 \cdot 30)\end{array}$ & & & \\
\hline B & $\begin{array}{r}1 \\
2 \\
4 \\
6 \\
8 \\
12 \\
24 \\
48\end{array}$ & $\begin{array}{r}3 \cdot 8 \\
20 \cdot 9 \\
46 \cdot 1 \\
56 \cdot 8 \\
64.9 \\
71.6 \\
76.4 \\
78 \cdot 4\end{array}$ & $\begin{array}{l}(1 \cdot 61) \\
(2.30) \\
(2 \cdot 41) \\
(3.94) \\
(5 \cdot 43) \\
(6 \cdot 10) \\
(6.90) \\
(6.90)\end{array}$ & $\begin{array}{l}0.014 \\
0.054 \\
0.153 \\
0.227 \\
0.278\end{array}$ & $\begin{array}{l}(4 \cdot 2) \\
(13 \cdot 8) \\
(29 \cdot 8) \\
(41 \cdot 8) \\
(50 \cdot 1)\end{array}$ & 0.17 \\
\hline C & $\begin{array}{l}1 \\
2 \\
4 \\
6 \\
8\end{array}$ & $\begin{array}{r}5 \cdot 2 \\
19 \cdot 1 \\
54 \cdot 7 \\
67 \cdot 2 \\
72 \cdot 6\end{array}$ & $\begin{array}{l}(2 \cdot 59) \\
(5 \cdot 89) \\
(3.81) \\
(4 \cdot 30) \\
(6 \cdot 74)\end{array}$ & & & \\
\hline
\end{tabular}

was in urine. Eight-hour cumulative excretion was similar in the three groups. In two subjects each in groups $\mathrm{A}$ and $B$ the 48-hour stool radioactivity indicated minimal excretion by this route. After a 500-mg. dose of L-dopa (group B) very little ${ }^{14} \mathrm{CO}_{2}$ was detected in expired air over an eight-hour period.

\section{Clinical Observations}

All patients who received L-dopa showed improvement in their Parkinson's disease. The improvement varied from moderate to impressive. The mean improvement with time in the patients studied is shown in the Chart. Improvement at $\mathbf{3 0}$ days averaged $47 \%$ and at 50 days $55 \%$. In the 10 patients treated for 100 days improvement averaged $60 \%$. Ten of the patients have received treatment for periods exceeding six 


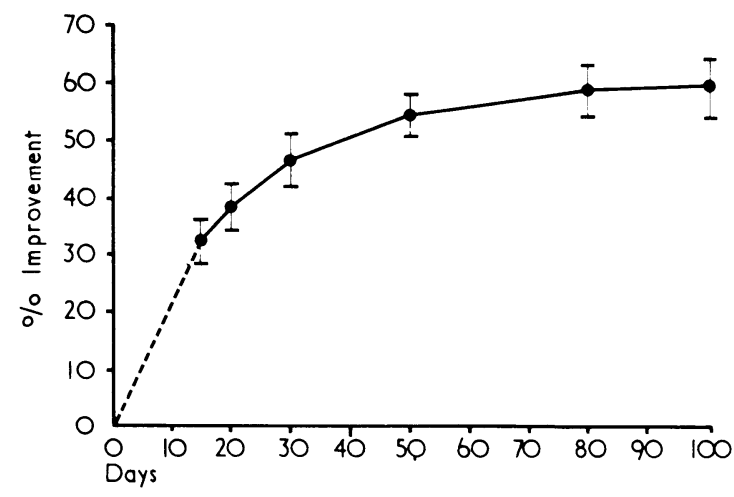

Mean percentage improvement with time \pm S.E. of mean in 22 patients receiving $\mathrm{L}$-dopa.

months. As reported in other studies, rigidity and bradykinesia were more clearly affected than tremor, though several patients with tremor showed definite improvement in this symptom. Percentage improvement at the last visit was correlated with age, sex, duration of disease, and severity of disability (Table IV). Higher improvement scores occurred in

TABLE IV.-Correlation of Percentage Improvement With Other Variables

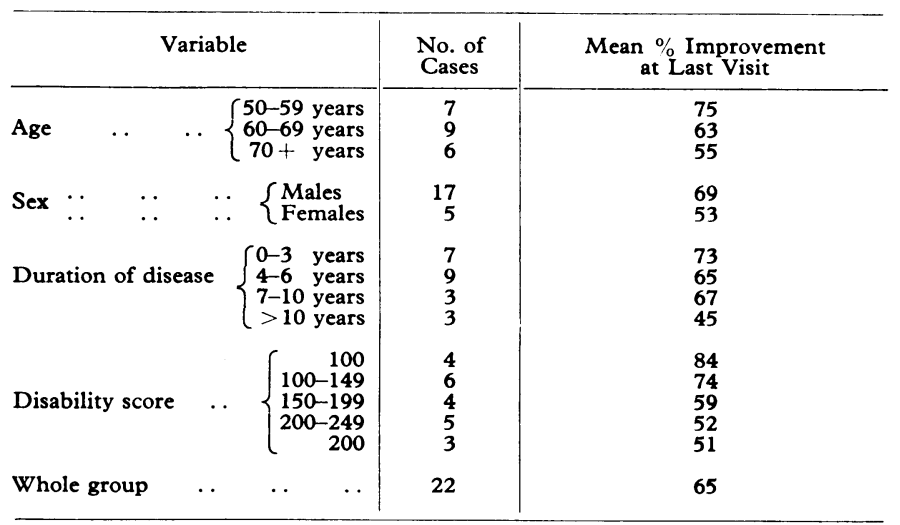

younger patients, in males as compared with females, in patients with disease of less than 10 years' duration, and in the less severely disabled patients.

Side-effects were frequent but never severe. The most common early side-effect was nausea, which was the early dose-limiting factor in most patients. In those patients who did not experience nausea, dosage was usually limited to $4 \mathrm{~g}$. a day, though the average tolerated dose was only $3 \mathrm{~g}$. a day. The side-effects observed are summarized in Table V.

TABLE V.-Side-Effects

\begin{tabular}{|c|c|c|c|c|c|c|}
\hline \multicolumn{3}{|c|}{ Side-Effect } & \multirow{2}{*}{ 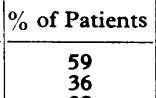 } & \multicolumn{2}{|l|}{ Side-Effect } & \multirow{2}{*}{$\begin{array}{c}\% \text { of Patients } \\
18 \\
18 \\
9 \\
23\end{array}$} \\
\hline $\begin{array}{l}\text { Nausea } \ldots \\
\text { Anorexia } \\
\text { Vomiting .. } \\
\text { Constipation }\end{array}$ & $\begin{array}{l}\ldots \\
\cdots \\
\cdots\end{array}$ & $\begin{array}{l}\ldots \\
\cdots \\
\cdots\end{array}$ & & $\begin{array}{l}\text { Dizziness } \\
\text { Hallucinations .. } \\
\text { Hyperkinesis .. } \\
\text { Choreoathetosis }\end{array}$ & $\begin{array}{l}\because \\
\because \\
\therefore\end{array}$ & \\
\hline
\end{tabular}

Choreoathetosis developed in some patients who received the drug for more than two months, and was reversible on stopping the drug for 48 hours and then continuing medication at a lower dosage. Routine laboratory investigations at each visit included haemoglobin, total and differential white cell counts, blood urea, blood sugar, plasma proteins, liver function tests, and direct Coombs test. None of these investigations showed significant variation or departure from the normal range.

\section{Discussion}

Results of the metabolic study show that L-dopa in both small and large doses is rapidly and completely absorbed from the gastrointestinal tract. Neither expired air nor stool represents a significant route of excretion for the drug or its metabolites. The occurrence of peak total radioactivity levels in serum at one to two hours after ingestion indicates rapid distribution. Serum was used in preference to plasma for technical convenience in the preparation of supernatants for fractionation of metabolites by column chromatography (to be published). Mean serum levels were $96 \%$ of plasma values. The low percentages of radioactivity found in venous blood suggest that the major source of metabolism lies before distribution in the blood stream-that is, in the gastrointestinal mucosa or the liver. The observation that proportions of drug or metabolites in serum were lower after therapeutic doses than after smaller doses of L-dopa suggests that in doses of $0.5 \mathrm{~g}$. or more rate-limiting steps in metabolic pathways may alter the distribution of metabolites. This is currently under investigation. Beyond three hours after ingestion the serum levels were closely comparable in the three groups, suggesting that any modification of metabolism induced by dose or pretreatment with the drug applies only to early handling of large doses, presumably by the liver.

Excretion of metabolites in urine occurred at a similar rate in the three groups, except that excretion rate was slightly greater in the pretreated patients. Since the differences are slight and the groups small, it is not possible to conclude that pretreatment with L-dopa enhances excretion of its metabolites.

The clinical evidence for the efficacy of the drug in Parkinson's disease is now established beyond doubt from several studies both of structured non-blinded investigations (Cotzias et al., 1969) and in double-blind controlled studies (Calne et al., 1969; Godwin-Austen et al., 1969). The observations reported here are further evidence that this drug represents a major advance in the treatment of Parkinson's disease.

Previous reports have suggested that improvement continues beyond three months (Yahr et al., 1968), and this is confirmed in the present study. The degree of improvement in most studies has been considerable, and closely comparable to that reported here. Less enthusiastic reports of efficacy may be explained by the shorter periods of treatment or by the smaller doses prescribed. The relevance of too early an assessment of improvement can be seen in the Chart. Previous reports have suggested that response to treatment does not depend on age, sex, or duration or severity of disease. The data presented here suggest that the younger the patient the greater is the response, that the less severe the disease the more likely is substantial improvement, and that patients who have had the disease for longer periods may be less likely to respond than those more recently afflicted. Though the women achieved lower improvement scores than the men, this may be explained by the fact that they were on average older than the men.

Experience with patients treated from the outset as outpatients suggests that this method of management is satisfactory provided that patients are informed of the possible symptoms such as nausea, dizziness, hallucinations, nightmares, agitation, and involuntary movements, and that supervision is both close and frequent. Dosage increments should be made less often during outpatient care. For optimum improvement to become manifest, continued treatment is necessary for several months. No patient in the present series was obliged to stop the drug because of uncontrollable sideeffects.

The degree of improvement in the patients reported here, who were already receiving drugs classically supposed to im- 
prove Parkinson's disease, is added testimony to the efficacy of the drug. It appears that L-dopa is now the drug of choice in the management of patients with this disease. This is not to deny that treatment at an optimum level requires frequent assessment and careful adjustment of dosage to the individual's particular needs, and that side-effects are frequent and of ten dose-limiting.

We express thanks to Dr. L. Lasagna and Dr. T. Preziozi for continued interest and support and to R. M. Hersey for invaluable technical help. Dr. A. Pletscher (Hoffman-La Roche, Basle, Switzerland) kindly supplied the ${ }^{1+} \mathrm{C}-\mathrm{L}-\mathrm{dopa}$, and Dr. W. B. Abrams (Hoffman-La Roche, Nutley, New Jersey) supplied the pure L-dopa used in these studies.

Requests for reprints should be addressed to Dr. M. J. T. Peaston.
REFERENCES

Alba, A., Trainor, F. S., Ritter, W., and Dacso, M. M. (1968). fournal of Chronic Diseases, 21, 507

Bray, G. A. (1960). Analytical Biochemistry, 1, 279.

Calne, D. B., Stern, G. M., Laurence, D. R., Sharkey, J., and Armitage, P. (1969). Lancet, 1, 744

Cotzias, G. C., Papavasiliou, P. S., and Gellene, R. (1968). Neurology (Minneapolis), 18, 276

Cotzias, G. C., Papavasiliou, P. S., and Gellene, R. (1969). New England fournal of Medicine, 280, 337

Fredrickson, D. S., and Ono, K. (1958). Fournal of Laboratory and Clinical Medicine, 51, 147.

Godwin-Austen, R. B., Tomlinson, E. B., Frears, C. C., and Kok, H. W. L. (1969). Lancet, 2, 165 .

Johns, R. J., and Draper, I. T. (1964). Bulletin of the Fohns Hopkins Hospital, 115, 447.

Kelly, R. G., Peets, E. A., Gordon, S., and Buyske, D. A. (1961). Analytical Biochemistry, 2, 267

Yahr, M. D., Duvoisin, R. C., Hoehn, M. M., Schear, M. J., and Barrett, R. E. (1968). Transactions of the American Neurological As sociation, $93,56$.

\title{
Studies of Australia-SH Antigen in Sporadic Viral Hepatitis in London
}

\author{
YVONNE E. COSSART, ${ }^{*}$ M.B., M.R.C.PATH. ; J. VAHRMAN, $†$ M.B., M.R.C.P.ED.
}

British Medical fournal, 1970, 1, 403-405

\begin{abstract}
ummary: Sera from 87 patients with acute sporadic viral hepatitis were tested for the presence of the Australia-SH antigen. Forty-three were positive by the complement-fixation test, but only 24 of these reacted in the gel-diffusion test. The antigen was equally distributed in infectious and serum hepatitis. The relationship of naturally occurring antigen-positive hepatitis to the Willowbrook MS-2 type is discussed.
\end{abstract}

\section{Introduction}

The relationship of the Australia-SH (Au-SH) antigen to the different types of viral hepatitis is still uncertain. The antigen may sometimes be detected in the serum early in the disease, but its frequency in infectious and serum hepatitis appears to vary widely (Table I). This variation is not likely to be due to difference in laboratory technique as good agreement was obtained when five " anti-Au-SH" sera were compared by the gel-diffusion method (Cossart, Taylor, Vahrman, and Zuckerman, 1969). It has recently been shown that much lower concentrations of antigen can be detected by the complementfixation test (Shulman and Barker, 1969). We have therefore used both the gel-diffusion and complement-fixation methods to examine sera from 87 cases of naturally occurring viral hepatitis admitted to the Western Hospital, London, during the past four years and have attempted to correlate the presence of the antigen with the clinical types of the disease.

\section{Patients Studied}

Blood and faecal specimens were obtained from 87 patients soon after admission to hospital. None had received blood transfusions and none were associated with a renal dialysis unit or admitted to using narcotic drugs. Patients with clinical or laboratory evidence of infectious mononucleosis or cytomegalovirus infection were excluded from the study. Though no deliberate selection was made material was not obtained

\footnotetext{
* Consultant Virologist, Virus Reference Laboratory, Colindale, London

$\dagger$ Consultant in Infectious Diseases, Western Hospital, London S.W.6.
}

from every patient with hepatitis. There was a period of 11 months after May 1966 during which collection of specimens was suspended.

Two types of viral hepatitis were distinguished: (1) infectious hepatitis (I.H.) with a short incubation period (15 to 40 days) after an injection, contact with another case, or a visit to an endemic area; and (2) serum hepatitis (S.H.) with a long incubation period (60 to 180 days) after an injection or with a history of arthralgia of the small joints.

Patients whose history contained no positive features of either category were placed in the I.H. group. In some patients there were points in favour of both diagnoses, and these have been considered as a third group.

\section{Laboratory Methods}

The same antiserum (L.B.) was used for both gel-diffusion and complement-fixation tests. It was obtained from a haemophiliac who had received many transfusions of blood, fresh frozen plasma, and cryoprecipitate. Its specificity has been compared with that of the anti-Au and anti-S.H. reference sera kindly supplied by Dr. B. S. Blumberg and Dr. A. M. Prince respectively. The three sera had almost identical properties in the gel-diffusion test (Cossart et al., 1969).

The gel-diffusion tests were performed in $1 \%$ agarose (Prince, 1968).

The complement-fixation tests were performed by a micromethod with a 4 ( $\times 0.02 \mathrm{ml}$.) volume technique, overnight fixation at $4{ }^{\circ} \mathrm{C}$., and $2 \frac{1}{2}$ units of complement; $50 \%$ endpoints were recorded.

All sera were inactivated at $56^{\circ} \mathrm{C}$. for one hour before use and serial twofold dilutions of sera from hepatitis patients were tested against one dilution of indicator serum L.B. which contained 4 units of antibody.

For the indirect test the initial mixtures which contained serial twofold dilutions of the patient's convalescent serum, and 4 units of antigen, were held for three hours at room temperature before serum L.B. and complement were added. Fixation was then allowed to proceed at $4^{\circ} \mathrm{C}$. overnight.

Ten per cent faecal extracts were made in Medium 199 and after centrifugation at 3,000 r.p.m. for 15 minutes the supernatant fluids were tested in the presence of antigen by gel 